\title{
26 Research Square \\ Summertime precipitation in Hokkaido and Kyushu, Japan in response to global warming
}

Daichi Takabatake ( $\nabla$ tkbd1070@gmail.com )

Japan Meteorological Agency https://orcid.org/0000-0002-4295-545X

Masaru Inatsu

Faculty of Science and Center for Natural Hazards Research, Hokkaido University

\section{Research Article}

Keywords: Clausius-Clapeyron relation, moisture flux convergence, multi-model ensemble, Asian monsoon, global warming

Posted Date: July 1st, 2021

DOl: https://doi.org/10.21203/rs.3.rs-286237/v1

License: (1) This work is licensed under a Creative Commons Attribution 4.0 International License.

Read Full License

Version of Record: A version of this preprint was published at Climate Dynamics on October 13th, 2021.

See the published version at https://doi.org/10.1007/s00382-021-05983-7. 


\section{Abstract}

We analyzed a large ensemble dataset called the database for Policy Decision Making for Future climate change (d4PDF), which contains 60-km resolution atmospheric general circulation model output and 20$\mathrm{km}$ resolution dynamical downscaling for the Japanese domain. The increase in moisture and precipitation, and their global warming response in June-July-August were described focusing on the differences between Hokkaido and Kyushu. The results suggested that the specific humidity increased almost following the Clausius Clapeyron relation, but the change in stationary circulation suppressed the precipitation increase, except for in western Kyushu. The $+4 \mathrm{~K}$ climate in Hokkaido would be as hot and humid as the present climate in Kyushu. The circulation change related to the southward shift of the jet stream and an eastward shift of the Bonin high weakened the moisture flux convergence via a stationary field over central Japan including eastern Kyushu. The transient eddy activity counteracted the increase in humidity, so that the moisture flux convergence and precipitation did not change much over Hokkaido. Because the contribution of tropical cyclones to the total precipitation was at most $10 \%$, the decrease in the number of tropical cyclones did not explain the predicted change in precipitation.

\section{Introduction}

Global warming leads to a hotter and wetter climate, especially in the subarctic and temperate zones (Collins et al. 2013). According to the Clausius-Clapeyron (CC) relation, a temperature increase of $1 \mathrm{~K}$ would increase the water vapor mixing ratio by approximately $7 \%$ if the relative humidity remained at the present level. Because precipitation is associated with the vertically integrated moisture flux convergence (MFC) in the time average, the increase in precipitation would also be approximately $7 \%$ with no changes in large-scale circulation structure. The precipitation increase above (below) $7 \%$ is called the super-CC (sub-CC) situation. Hence, whether the local precipitation response to global warming is super-CC or subCC depends mainly on the change in MFC caused by not only the mean flow, but also transient eddies, such as extratropical cyclones, typhoons, and subtropical front modulation.

Summertime precipitation over Japan is mainly from moisture intrusion from southeast Asia, and the effect of this precipitation is greater in western Japan than in Hokkaido. Future changes in summertime precipitation are sensitive to the subtropical anticyclone called the Bonin high in the south of Japan, which primarily controls the positions and persistency of the Baiu front and meso-scale cyclones moving on it. In the model inter-comparison of the 5th Coupled Model Intercomparison Project (CMIP5), global warming substantially shifted the Bonin high and Asian rainbelt eastward (He et al. 2015), although whether the high pressure is enhanced or suppressed is inconclusive (He and Zhou 2015). Despite the large uncertainty, the precipitation projection from most models shows increases in western Japan related to the intensified Asian summer monsoon (Hsu et al. 2012; Lee and Wang 2012; Kawase et al. 2009). Although a northward shift of the Baiu/Meiyu front has been observed as a trend (Ninomiya 2011), the more recent model has suggested the delay of the northward shift in the future climate (Kusunoki and Mizuta 2012; Kanada et al. 2012; Okada et al. 2017), which is consistent with earlier studies with a coarser global model experiment (Kimoto et al. 2005; Kusunoki et al. 2006). The dynamical 
downscaling (DDS) projection also showed that Baiu-related heavy rainfall increased greatly in northern Japan but decreased in eastern Japan (Osakada and Nakakita 2018; Hatsuzuka and Sato 2019). Moreover, heavy rainfall in Japan was often caused by typhoons (Utsumi et al. 2017) that moved along the western fringe of the Bonin high. In the present consensus, global warming decreases typhoon frequency over the western North Pacific due to more stable stratification, but increases the number of category 4 and 5 typhoons due to moisture enrichment arising from higher sea surface temperatures (Knutson et al. 2010). Typhoons rarely approach northern Japan owing to its cool and dry environment under the present climate, although there has been an increase in typhoon-related extreme rainfall over Hokkaido (Hatsuzuka et al. 2020).

One approach to predicting the response of rare phenomena to global warming is performing a pseudo global warming simulation for an individual event (Ito et al. 2016; Kanada et al. 2017). For example, Kanada et al. (2019) analyzed typhoon-related precipitation for an event in August 2016 only and found that heavy rainfall became more frequent and light rainfall became less frequent in eastern Hokkaido. However, the pseudo-global warming experiment indicated how a typhoon event and its related precipitation would change in a future climate only, and did not predict how many typhoon events there would be. Moreover, the experiment did not reveal the future probability of heavy rainfall nor the contribution of typhoons to future precipitation changes. To analyze these rainfall characteristics, we need a huge number of realizations to compute the statistics with a sufficient number of typhoon events. Recently, thousands of year ensemble simulations with an atmospheric general circulation model (AGCM) were performed with 60-km resolution under the present climate from 1950 to 2010 , and the $+2 \mathrm{~K}$ and $+4 \mathrm{~K}$ climates relative to the pre-industrial era (Mizuta et al. 2017; Fujita et al. 2019). This dataset was archived as the database for Policy Decision Making for Future climate change (d4PDF). Moreover, part of the d4PDF global data was dynamically downscaled to 20-km resolution for the Japanese domain. This DDS dataset showed an increase in extreme precipitation in response to global warming. Hence, the d4PDF dataset is likely to be helpful in evaluating precipitation changes over Hokkaido in future climates and analyze the contribution of typhoons that rarely make landfall there.

The purpose of this paper is to describe how much global warming increases the amount of moisture in the climate and how it changes rainfall characteristics. We focus on Hokkaido (northernmost of the main islands of Japan; Fig. 1) and Kyushu (southern- and westernmost of the main islands of Japan). Hokkaido is rarely affected by the Baiu rainband and typhoons under the present climate, whereas the other Japanese regions are affected by both phenomena. Kyushu is located where low-level moist air from the southwest and upper-level dry air from the west meet. Torrential rainfall is frequently observed in Kyushu related to the Asian summer monsoon (Ogura et al. 1985; Kato 1998; Moteki et al. 2004), and recent events have triggered serious disasters (e.g., Hirockawa et al. 2021). Hence, the contrast between Hokkaido and Kyushu highlights how global warming changes dry and moist climates in summer. The remainder of the paper is organized as follows. Section 2 describes d4PDF data and Section 3 explains the methodology, including the definition of tropical cyclones (TCs) and the Baiu rainband. We use the term 'TC' instead of 'typhoon' for the cyclones oriented in the tropics that are calculated in atmospheric models. Section 4 shows the predicted results of the moistening of the Hokkaido climate. Section 5 
shows the predicted results of the precipitation increase in Hokkaido, with the contribution of TC and Baiu front changes in response to global warming. We compare the results for Hokkaido with those for Kyushu. Section 6 concludes the paper.

\section{Data}

We used the large ensemble climate simulation dataset, d4PDF (Mizuta et al. 2017; Fujita et al. 2019). The d4PDF dataset consists of a global experiment using the Meteorological Research Institute's AGCM with $60-\mathrm{km}$ resolution and a regional experiment obtained by DDS of the Nonhydrostatic Regional Climate Model with 20-km resolution for a domain covering Japan. The d4PDF runs were conducted for the historical climate for the 60 years between 1951 and 2010 (HIST run), a climate warming by $2 \mathrm{~K}$ for the 60 years prior to 2040 under the Representative Concentration Pathway 8.5 scenario with the Intergovernmental Panel on Climate Change (2K run), and a climate warming by $4 \mathrm{~K}$ for the 60 years prior to 2090 (4K run). The HIST run had 100 ensembles for global model experiments and 50 ensembles for the DDS. The $2 \mathrm{~K}$ and $4 \mathrm{~K}$ runs had 54 and 90 ensembles, respectively, for both the global model experiment and DDS. We mainly analyzed 6-hourly air temperature and specific humidity at $850 \mathrm{hPa}$ in the global model output and hourly variables of wind speed, temperature, and relative humidity just above the surface and precipitation in DDS. The target area was the domain $41^{\circ}-46^{\circ} \mathrm{N}$ and $139^{\circ}-147^{\circ} \mathrm{E}$ including Hokkaido, and $30^{\circ}-35^{\circ} \mathrm{N}$ and $128^{\circ}-133^{\circ} \mathrm{E}$ including Kyushu (Fig. 1). The analysis was limited to the boreal summer in June-July-August (JJA).

\section{Method}

\subsection{Moisture budget analysis}

For the moisture budget in a unit column, the climatological MFC approximately equals

precipitation intensity $P$ minus evaporation intensity $E$ as

$$
\left\langle-\frac{1}{g} \nabla_{\mathrm{H}} \cdot \int_{p_{T}}^{p_{s}} q v d p\right\rangle+\left\langle\frac{q_{s}}{g} \nabla_{\mathrm{H}} \cdot \int_{p_{T}}^{p_{s}} v d p\right\rangle \sim\langle P\rangle-\langle E\rangle,
$$

where $\nabla_{\mathrm{H}}$ is the horizontal differential operator, $v$ is the horizontal wind vector, $q$ is

the specific humidity, $q_{s}$ is the specific humidity above the surface, $p_{s}$ is the surface

pressure, $p_{T}$ is $200 \mathrm{hPa}, g$ is gravity, and $\langle\cdot\rangle$ denotes climatology. We neglected the

second term on the left-hand side only because it was difficult to estimate accurately from the 6-hourly dataset, which could cause a considerable error in the steep slope region. The first term on the left-hand 
side is separated into the MFC from climatological wind and from transient eddies as

$$
-\frac{1}{g} \nabla_{\mathrm{H}} \cdot \int_{p_{T}}^{p_{s}}\langle q\rangle\langle v\rangle d p-\frac{1}{g} \nabla_{\mathrm{H}} \cdot \int_{p_{T}}^{p_{s}}\left\langle q^{\prime} v^{\prime}\right\rangle d p \sim\langle P\rangle-\langle E\rangle .
$$

Here, the prime denotes the transient-eddy component. Moreover, applying the difference operator to Eq. (2),

$$
\begin{gathered}
-\frac{1}{g} \nabla_{\mathrm{H}} \cdot \int_{p_{T}}^{p_{s}}\langle v\rangle \delta\langle q\rangle d p-\frac{1}{g} \nabla_{\mathrm{H}} \cdot \int_{p_{T}}^{p_{s}}\langle q\rangle \delta\langle v\rangle d p \\
-\frac{1}{g} \nabla_{\mathrm{H}} \cdot \int_{p_{T}}^{p_{s}} \delta\left\langle q^{\prime} v^{\prime}\right\rangle d p \sim \delta\langle P\rangle,
\end{gathered}
$$

by assuming $\delta\langle E\rangle \sim 0$. The first term is the MFC difference due to moisture change and

the second term is the MFC difference due to circulation change. The third term is the MFC difference due to the change of transient eddy activity. If the second and third terms were zero and the moisture change almost followed the $\mathrm{CC}$ relation, the precipitation change would also follow the $\mathrm{CC}$ relation. Otherwise, the precipitation change would be interpreted as the super-CC or the sub-CC situation.

\subsection{TCs and the Baiu front}

The TC tracking was originally performed with a simpler parameter set than Yoshida et al. (2017), but the set was extended after the extratropical transition based on 6-hourly data from the d4PDF global experiments. The TC central positions in the tracking data were linearly interpolated to hourly intervals. The TC precipitation was defined as rainfall within $500 \mathrm{~km}$ from the TC center, and the non-TC precipitation was defined as rainfall elsewhere. Moreover, the Baiu front was located at the southern edge

of the subtropical jet stream, the axis of which was identified by the latitudes where the zonal wind at 500 $\mathrm{hPa}$ averaged over the longitudes $130^{\circ}-140^{\circ} \mathrm{E}$ reached its maximum.

\section{Results}

4.1 Climatological temperature and moisture response

The JJA mean temperature at $850 \mathrm{hPa}$ was $12-18^{\circ} \mathrm{C}$ and the JJA mean specific humidity at $850 \mathrm{hPa}$ was $6-11 \mathrm{~g} \mathrm{~kg}^{-1}$, from Hokkaido to Kyushu in the HIST run of the AGCM experiments (Fig. 2). Because moisture is advected from the southeast of Japan, the isopath of the specific humidity along the Japanese Archipelago crossed isotherms. Abundant moisture intruded along the western fringe of the Bonin high. The pentad temperatures averaged over the Hokkaido domain almost followed the normal distribution with an average of $13.0^{\circ} \mathrm{C}$ and a standard deviation of $2.8^{\circ} \mathrm{C}$, whereas those averaged over the Kyushu domain were positively skewed with a small variation (Fig. 3a). This is probably because of 
the contrast between the dominant fluctuation caused by the passage of extratropical cyclones in the subarctic zone and the uniformly warm temperature that prevails in a subtropical downdraft area. Similar to the probability density function of the pentad temperature, the specific humidity followed the normal distribution of the average at $7.5 \mathrm{~g} \mathrm{~kg}^{-1}$ in Hokkaido and the positively skewed distribution of $5-15 \mathrm{~g}$ $\mathrm{kg}^{-1}$ in Kyushu (Fig. 3b). These climatological features in the HIST run were similar to the observed features.

The $2 \mathrm{~K}$ run showed an increase in climatological temperature of $1.5-2 \mathrm{~K}$ and an increase in climatological specific humidity of $10-15 \%$ (Fig. 4a), both with a statistical significance of $5 \%$ over almost all of the target domain (not shown). Because the $1 \mathrm{~K}$ increase in temperature corresponds to a $7 \%$ increase in water vapor amount, this almost followed the $\mathrm{CC}$ relation as well. Moreover, the $4 \mathrm{~K}$ run showed a temperature increase of $4-4.5 \mathrm{~K}$ over Japan (Fig. $4 \mathrm{~b}$ ). The specific humidity increased by approximately $28 \%$ in Kyushu and approximately $35 \%$ in Hokkaido, almost following the CC relation. The temperature and moisture increase exceeded the statistical significance level of $5 \%$ (not shown). This result suggested that hot, humid environment in Hokkaido in the $+4 \mathrm{~K}$ climate was comparable to that in Kyushu in present climate (Fig. 3).

\subsection{Climatological circulation and precipitation response}

The d4PDF DDS simulation captured the observed precipitation over Japan in JJA well (Figs. 5, 6). Hokkaido had average precipitation of about $3 \mathrm{~mm} \mathrm{day}^{-1}$, whereas Kyushu had an average of about 10 $\mathrm{mm}$ day $^{-1}$. The total amount of precipitation in JJA exceeded $1000 \mathrm{~mm}$ along the Pacific side of the Japanese Archipelago due to the effect of topography. The summertime monsoonal flow converged abundant moisture from the southwest. Overall, the MFC showed the flux convergence over Japan, and the second term of the left-hand side of Eq. (1) was positive for the windward side around central Japan and negative on the leeward side. This was related to the persistent Baiu front in June and July, but the front did not affect the climate in Hokkaido greatly.

The summertime precipitation difference between the $4 \mathrm{~K}$ and HIST runs is shown in the shading of Fig. 7. This result was not sensitive to the sea surface temperature anomaly imposed in the AGCM (not shown). The precipitation decreased by $\sim 1 \mathrm{~mm}$ day $^{-1}$ (10-20\%) almost over central Japan including eastern Kyushu. However, in the $4 \mathrm{~K}$ run, the precipitation in Hokkaido increased slightly, especially in the south, and the precipitation in western Kyushu increased by $>2 \mathrm{~mm}^{-1 a y}{ }^{-1}(20-30 \%)$ (Fig. 7). The change in precipitation approximated the MFC changes (see Section 3.2), which can be divided into the effects of moisture content, climatological flow, and transient eddy activity. Based on the positive MFC on the windward side of Japan and negative MFC on the leeward side near high mountains, we explain why the precipitation increased slightly in Hokkaido, decreased in eastern Kyushu, and increased in western Kyushu.

Figure 8a displays the total MFC difference between the 4K and HIST runs. Despite a considerable error in the moisture budget around the steep slope area, the vertically integrated MFC between $4 \mathrm{~K}$ and 
HIST runs decreased over central Japan including eastern Kyushu, but showed a slight difference in Hokkaido and in western Kyushu (Fig. 8a, with the same shading as Fig. 7). Figure 8b shows the stationary response of MFC, which was positive over Hokkaido and western Kyushu and negative over southern Japan including eastern Kyushu. The response was divided into the contributions from moisture change (Fig. 8c) and circulation change (Fig. 8d). Consistent with the CC relation (Fig. 4b), the $4 \mathrm{~K}$ run provided an almost uniform increase in MFC due to the increase in humidity. A patchy decrease in the MFC over Japan was caused by the horizontal convergence/divergence pattern that emerged below 850 $\mathrm{hPa}$ around the mountain region. In contrast, the MFC due to circulation change decreased significantly over central Japan including eastern Kyushu, but we found a patchy increase in the MFC in western Kyushu. This result was probably related to the change in monsoonal flow direction in the 4K run (Fig. 7). The climatological summertime wind over Kyushu was southwesterly and the MFC was positive. The wind response to global warming was westerly or northwesterly over Kyushu, which strengthened the wind convergence in western Kyushu and weakened it in eastern Kyushu.

Figures 9a, c show the seasonal march of the climatological jet stream at $500 \mathrm{hPa}$ averaged over longitudes of $130-140^{\circ} \mathrm{E}$. The HIST run reproduced the jet stream axis in June and July, although it had a southward bias (Fig. 9a). The Baiu front was mostly located on the southern edge of the jet core in the mid-troposphere. In the observations, the Baiu front gradually moved northward from June and ended at the end of July. The jet stream tended to be shifted southward in the Baiu season in the global warming simulations (Fig. 9c), consistent with previous studies with a different model or multiple model comparison (Kawase et al. 2009; Horinouchi et al. 2019). The shift was $200 \mathrm{~km}$ in the $4 \mathrm{~K}$ run and left the rainband far from the central Japanese islands. This was closely related to an eastward shift of the Bonin high (Figs. 9b, d).

In summary, the precipitation increase in western Kyushu explained the MFC increase by strengthening the horizontal wind convergence and increasing the amount of moisture following the CC relation. The precipitation decrease in eastern Kyushu explained the MFC decrease by weakening wind convergence, which surpassed the effect of moisture enrichment. However, we could not explain the slight increase in precipitation over Hokkaido in the limited analysis of the climatological field.

\subsection{Effect of transient eddies}

Figure 10 shows HIST's climatology and the difference between the $4 \mathrm{~K}$ and HIST runs. The difference between the total MFC and the MFC caused by the climatological field (Fig. 10d) is the MFC caused by transient fluctuations, including extratropical cyclones and TCs, which was negative over Hokkaido and positive off the Pacific coast of Japan. However, in Hokkaido, this transient response had the opposite sign to the stationary response, so that the response of the total MFC (Fig. 8a) was slightly weaker than that of the MFC caused by the climatological field (Fig. 8b). In the HIST run, storm activity estimated with the band-pass-filtered meridional wind variance reached its maximum around $50^{\circ} \mathrm{N}$ (Fig. 10b). The difference between the $4 \mathrm{~K}$ and HIST runs decreased significantly, presumably related to the southward shift of the jet stream (Figs. 9, 10a). The northward moisture flux caused by band-pass eddies also 
decreased in response to global warming at $35-40^{\circ} \mathrm{N}$. This decrease weakened the eddy moisture flux to the north, and the MFC difference caused by transient eddies was negative over Hokkaido and positive over the south of Japan (Fig. 10d). In summary, the band-pass-filtered eddies like extratropical cyclones contributed to the decrease in MFC over Hokkaido, which counteracted the increase in MFC caused by the moisture enrichment following the $\mathrm{CC}$ relation.

The transient eddies contained TCs, some of which approached Japan along the western fringe of the Bonin high. The number of TCs, including the stage after extratropical transition, approaching Hokkaido was 0.4-1.0 per JJA in the HIST run, which was consistent with the observations. The contribution of TCs to the total precipitation in JJA was 1-3\% in Hokkaido (Fig. 11a). The percentage was higher in eastern Hokkaido, whereas Kyushu had more than two TCs per JJA on average in the HIST run, and the TC effect was greater in eastern and southern Kyushu (Fig. 11b). Because the TCs were much more intense when they passed near Kyushu, the contribution to the total precipitation exceeded $7 \%$ in eastern Kyushu and was 3\% even in western Kyushu (Fig. 11b). This west-east contrast has been already reported by Tamaki et al. (2018) and Kawase et al. (2019).

Overall, the $2 \mathrm{~K}$ and $4 \mathrm{~K}$ runs showed an increase in the JJA precipitation over Hokkaido and western Kyushu. The number of TCs approaching Hokkaido per JJA was $0.4-0.8$ in the $2 \mathrm{~K}$ run and $<0.5$ in the $4 \mathrm{~K}$ run, and this decrease was consistent with Yoshida et al. (2017). Despite the decrease in the number of TCs, the rate of change of TC-related precipitation remained almost constant in southern Hokkaido and increased toward the north in the $2 \mathrm{~K}$ and $4 \mathrm{~K}$ runs (Figs. 12a, c). The increase in precipitation reached $50 \%$ in the northernmost part of Hokkaido. This is because a single TC brought precipitation of $11.4 \mathrm{~mm} /$ day over Hokkaido in the $4 \mathrm{~K}$ run, much larger than precipitation from a single TC at $6.9 \mathrm{~mm} /$ day in the HIST run (Fig. 13). In contrast, the TC-related rainfall decreased substantially, by $10-20 \%$ in the $2 \mathrm{~K}$ run and $>30 \%$ in the $4 \mathrm{~K}$ run over Kyushu. The number of TCs approaching Kyushu decreased to $1.5-2$ in the $2 \mathrm{~K}$ run and $0.5-1$ in the $4 \mathrm{~K}$ run (Figs. $12 \mathrm{~b}, \mathrm{~d}$ ), whereas the precipitation from a single TC increased by $20 \%$ in the $2 \mathrm{~K}$ run and by $47 \%$ in the $4 \mathrm{~K}$ run following the increase in temperature (Fig. 13). Although the TCs passing through Kyushu became more intense, the TC contribution to total precipitation decreased because the TCs were less frequent. The decrease in total precipitation in eastern Kyushu (Fig. 7) was partly attributed to the decrease in the frequency of TCs passing through Kyushu. However, the decrease in TC frequency was not the primary reason why the total precipitation in JJA decreased, even in eastern Kyushu, because the contribution of TCs to the total precipitation was only $10 \%$ (Fig. 11). Instead, the primary reason was the climatological wind response to global warming (Figs. 7, 8d) associated with the eastward shift of the Bonin high (Figs. 9b, d).

\section{Conclusion}

We analyzed the large ensemble d4PDF dataset, which contains $60-\mathrm{km}$ resolution AGCM output and 20$\mathrm{km}$ resolution DDS for the Japanese domain, to describe the increase in moisture and precipitation in response to global warming. We focused on contrasting Hokkaido with Kyushu because the summer Asian monsoon affected Kyushu's climate much more than Hokkaido's. The specific humidity increased 
by $~ 35 \%$ in Hokkaido and by $~ 28 \%$ in Kyushu, following the CC relation (Fig. 4). The hot, humid environment in Hokkaido under the $+4 \mathrm{~K}$ climate was comparable to the present climate in Kyushu (Fig. 3). Although the increase in moisture followed the CC relation, the precipitation was also changed by changes in circulation. The DDS output of d4PDF simulated a slight increase in precipitation over Hokkaido, an increase in western Kyushu, and a decrease in eastern Kyushu (Fig. 7). Because the increase was below the CC level in Hokkaido and in western Kyushu, the circulation decreased the total precipitation over Japan. The change in circulation was related to an eastward shift in the Bonin high and a southern shift in the subtropical jet stream in the Japanese longitudes. The transient response that counteracted the stationary response decreased the MFC in Hokkaido and increased it in the south of Japan. Because the contribution of TCs to the total precipitation in JJA was at most 10\% (Fig. 11), the decrease in the number of TCs was not the main reason why the precipitation changed in the DDS simulation.

\section{Declarations}

\section{Conflict of Interest}

The authors declare no conflicts of interest associated with this paper.

\section{Acknowledgments}

$\mathrm{MI}$ is supported by JSPS KAKENHI grants (18K03734, 18H03819, and 19H00963), by the Integrated Research Program for Advancing Climate Models (TOUGOU) grant number JPMXD0717935457 of Ministry of Education, Sports, Culture, Science and Technology (MEXT), by the Environment Research and Technology Development Fund JPMEERF20192005 of the Environmental Restoration and Conservation Agency of Japan, and by Research Field of Hokkaido Weather Forecast and Technology Development (endowed by Hokkaido Weather Technology Center Co. Ltd.). This study used d4PDF produced with the Earth Simulator of the Japan Agency for Marine-Earth Science and Technology jointly by the MEXT science programs SOUSEI, TOUGOU, and SI-CAT.

\section{References}

1. Adler FR, Huffman GJ, Chang A, Ferraro R, Xie P, Janowiak J, Rudolf B, Schneider U, Curtis S, Bolvin D, Gruber A, Susskind J, Arkin P, Nelkin E (2003) The Version-2 Global Precipitation Climatology Project (GPCP) Monthly Precipitation Analysis (1979-Present). J Hydrometeorol 4:1147-1167

2. https://doi.org/10.1175/1525-7541(2003)004\%3C1147:TVGPCP\%3E2.0.CO;2

3. Collins M, Knutti R, Arblaster J, Dufresne JL, Fichefet T, Friedlingstein P, Gao X, Gutowski WJ, Johns T, Krinner G, Shongwe M, Tebaldi C, Weaver AJ, Wehner M (2013) Long-term climate change: Projections, commitments and irreversibility. Climate Change (2013) The Physical Science Basis. Contribution of Working Group I to the Fifth Assessment Report of the Intergovernmental Panel on 
Climate Change, Stocker, T. F., D. Qin, G.-K. Plattner, M Tignor, S. K. Allen, Boschung J, Nauels A, Xia Y, V. Bex and P. M. Midgley, Eds., Cambridge University Press, Cambridge, United Kingdom and New York, NY, USA

4. Fujita M, Mizuta R, Ishii M, Endo H, Sato T, Okada Y, Kawazoe S, Sugimoto S, Ishihara K, Watanabe S (2019) Precipitation changes in a climate with 2-K surface warming from large ensemble simulations using 60-km global and 20-km regional atmospheric models. Geophys Res Lett 46:435-442

5. https://doi.org/10.1029/2018GL079885

6. Hatsuzuka D, Sato T (2019) Future changes in monthly extreme precipitation in Japan using largeensemble regional climate simulations. J Hydrometeorol 20:563-574

7. https://doi.org/10.1175/JHM-D-18-0095.1

8. Hatsuzuka D, Sato T, Yoshida K, Ishii M, Mizuta R (2020) Regional projection of tropical-cycloneinduced extreme precipitation around Japan based on large ensemble simulations. Scientific Online Letters on the Atmosphere 16:23-29 https://doi.org/10.2151/sola.2020-005

9. He C, Zhou T (2015) Response of the western North Pacific subtropical high to global warming under RCP4.5 and RCP8.5 scenarios projected by 33 CMIP5 models: The dominance of tropical Indian Ocean-Tropical western Pacific SST gradient. J Clim 28:365-380 https://doi.org/10.1175/JCLI-D13-00494.1

10. He C, Zhou T, Lin A, Wu B, Gu D, Li C, Wang B (2015) Enhanced or weakened western North Pacific subtropical high under global warming? Sci Rep 5:16771 https://doi.org/10.1038/srep16771

11. Hirockawa Y, Kato T, Araki K, Mashiko W (2020) Characteristics of an extreme rainfall event in Kyushu district, southwestern Japan in early July 2020. Scientific Online Letters on the Atmosphere 16:265-270 https://doi.org/10.2151/sola.2020-044

12. Hsu PC, Li T, Luo JJ, Murakami H, Kitoh A, Zhao M (2012) Increase of global monsoon area and precipitation under global warming: A robust signal? Geophys Res Lett 39:L06701 https://doi.org/10.1029/2012GL051037

13. Horinouchi T, Matsumura S (2019) Jet-precipitation relation and future change of the Mei-Yu-Baiu rainband and subtropical jet in CMIP5 coupled GCM simulations. J Clim 32:22472259 https://doi.org/10.1175/JCLI-D-18-0426.1

14. Ito R, Takemi T, Arakawa O (2016) A possible reduction in the severity of typhoon wind in the northern part of Japan under global warming: A case study. Scientific Online Letters on the Atmosphere 12:100-105 https://doi.org/10.2151/sola.2016-023

15. Kanada S, Aiki H, Tsuboki K, Takayabu I (2019) Future changes in typhoon-related precipitation in eastern Hokkaido. Scientific Online Letters on the Atmosphere 15:244259 https://doi.org/10.2151/sola.2019-044

16. Kanada S, Tsuboki K, Aiki H, Tsujino S, Takayabu I (2017) Future enhancement of heavy rainfall events associated with a typhoon in the midlatitude regions. Scientific Online Letters on the Atmosphere 13:246-251 https://doi.org/10.2151/sola.2017-045 
17. Kanada S, Nakano M, Kato T (2012) Projections of future changes in precipitation and the vertical structure of the frontal zone during the Baiu season in the vicinity of Japan using a 5-km-mesh regional climate model. J Meteorol Soc Jpn 90:65-86 https://doi.org/10.2151/jmsj.2012-A03

18. Kato $T$ (1998) Numerical simulation of the band-shaped torrential rain observed over southern Kyushu, Japan on 1 August 1993. J Meteorol Soc Jpn 76:97$128 \mathrm{https}: / /$ doi.org/10.2151/jmsj1965.76.1_97

19. Kawase H, Yoshikane T, Hara M, Hara F, Yasunari T, Ailikun B, Ueda H, Inoue T (2009) Intermodel variability of future changes in the Baiu rainband estimated by the pseudo global warming downscaling method. J Geophys Res 114:1-14 https://doi.org/10.1029/2009JD011803

20. Kawase H, Imada Y, Sasaki H, Nakaegawa T, Murata A, Nosaka M, Takayabu I (2019) Contribution of historical global warming to local-scale heavy precipitation in western Japan estimated by large ensemble high-resolution simulations. J Geophys Res 124:60936103 https://doi.org/10.1029/2018JD030155

21. Kimoto M, Yasutomi N, Yokoyama C, Emori S (2005) Projected changes in precipitation characteristics around Japan under the global warming. Scientific Online Letters on the Atmosphere 1:85-88 https://doi.org/10.2151/sola.2005-023

22. Knutson TR, McBride JL, Chan J, Emanuel K, Holland G, Landsea C, Held I, Kossin JP, Srivastava AK, Sugi M (2010) Tropical cyclones and climate change. Nat Geosci 3:157$163 \mathrm{https}: / /$ doi.org/10.1038/ngeo779

23. Kusunoki S, Mizuta R (2012) Comparison of near future (2015 - 2039) changes in the East Asian rain band with future $(2075-2099)$ changes projected by global atmospheric models with $20-\mathrm{km}$ and $60-\mathrm{km}$ grid size. Scientific Online Letters on the Atmosphere 8:7376 https://doi.org/10.2151/sola.2012-019

24. Kusunoki S, Yoshimura J, Yoshimura H, Noda A, Oouchi K, Mizuta R (2006) Change of Baiu rain band in global warming projection by an atmospheric general circulation model with a 20-km grid size. J Meteorol Soc Jpn 84:581-611 https://doi.org/10.2151/jmsj.84.581

25. Lee JY, Wang B (2014) Future change of global monsoon in the CMIP5. Clim Dyn 42:101119 https://doi.org/10.1007/s00382-012-1564-0

26. Mizuta R, Murata A, Ishii M, Shiogama H, Hibino K, Mori N, Arakawa O, Imada Y, Yoshida K, Aoyagi T, Kawase H, Mori M, Okada Y, Shimura T, Nagatomo T, Ikeda M, Endo H, Nosaka M, Arai M, Takahashi C, Tanaka K, Takemi T, Tachikawa Y, Temur K, Kamae Y, Watanabe M, Sakaki H, Kitoh A, Takayabu I, Nakakita E, Kimoto M (2017) Over 5,000 years of ensemble future climate simulations by $60-\mathrm{km}$ global and 20-km regional atmospheric models. Bull Am Meteor Soc 98:13831398 https://doi.org/10.1175/BAMS-D-16-0099.1

27. Moteki Q, Uyeda H, Maesaka T, Shinoda T, Yoshizaki M, Kato T (2004) Structure and development of two merged rainbands over the East China Sea during X-BAIU-99. Part I. Meso- $\beta$-scale structure and development processes. J Meteorol Soc Jpn 82:19-44 https://doi.org/10.2151/jmsj.82.19 
28. Ninomiya K (2011) Characteristics of the Meiyu and Baiu frontal precipitation zone in the CMIP3 20th century simulation and 21st century projection. J Meteorol Soc Jpn 89:151159 https://doi.org/10.2151/jmsj.2011-204

29. Ogura Y, Asai T, Dohi K (1985) A case study of a heavy precipitation event along the Baiu front in northern Kyushu, 23 July 1982: Nagasaki heavy rainfall. Journal of the Meteorological Society of Japan 63:883-900 https://doi.org/10.2151/jmsj1965.63.5_883

30. Okada Y, Takemi T, Ishikawa H, Kusunoki S, Mizuta R (2017) Future changes in atmospheric conditions for the seasonal evolution of the Baiu as revealed from projected AGCM experiments. $J$ Meteorol Soc Jpn 95:239-260 https://doi.org/10.2151/jmsj.2017-013

31. Osakada Y, Nakakita E (2018) Future change of occurrence frequency of Baiu heavy rainfall and its linked atmospheric patterns by multiscale analysis. Scientific Online Letters on the Atmosphere 14:79-85 https://doi.org/10.2151/sola.2018-014

32. Tamaki Y, Inatsu M, Nguyen-Le D, Yamada TJ (2018) Heavy rainfall duration bias in dynamical downscaling and its related synoptic patterns in summertime Asian monsoon. Journal of Applied Meteorology Climatology 57:1477-1496 https://doi.org/10.1175/JAMC-D-17-0116.1

33. Utsumi N, Kim H, Kanae S, Oki T (2017) Relative contributions of weather systems to mean and extreme global precipitation. J Geophys Res 122:152-167 https://doi.org/10.1002/2016JD025222

34. Yoshida K, Sugi M, Mizuta R, Murakami H, Ishii M (2017) Future changes in tropical cyclone activity in high-resolution large-ensemble simulations. Geophys Res Lett 44:99109917 https://doi.org/10.1002/2017GL075058

\section{Figures}




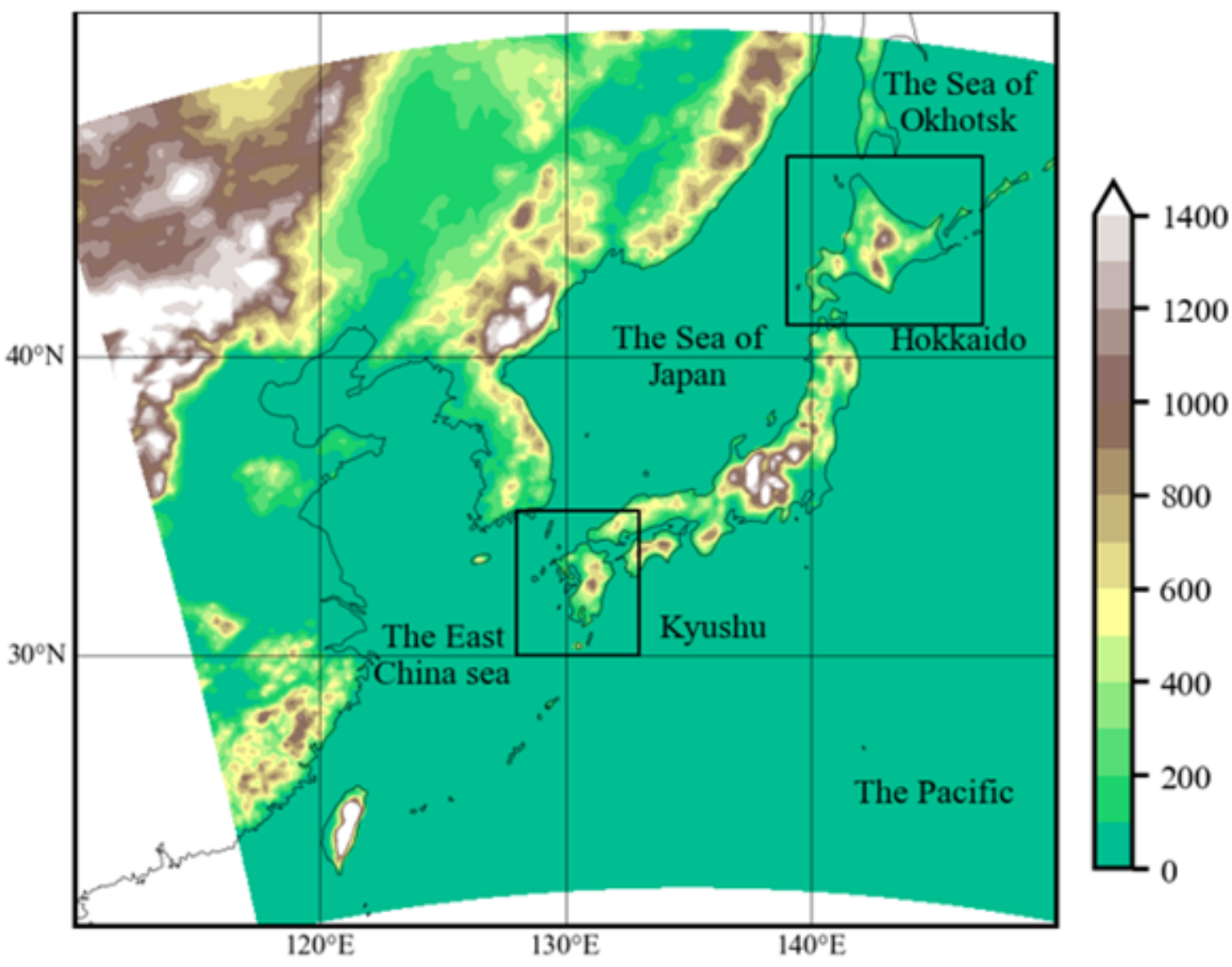

Figure 1

Map of the study area. The Hokkaido and Kyushu domains are enclosed by rectangles. Color shading as per the scale on the right shows surface height above the sea level used in the $20-\mathrm{km}$ resolution simulation. The colored region is the model domain. 


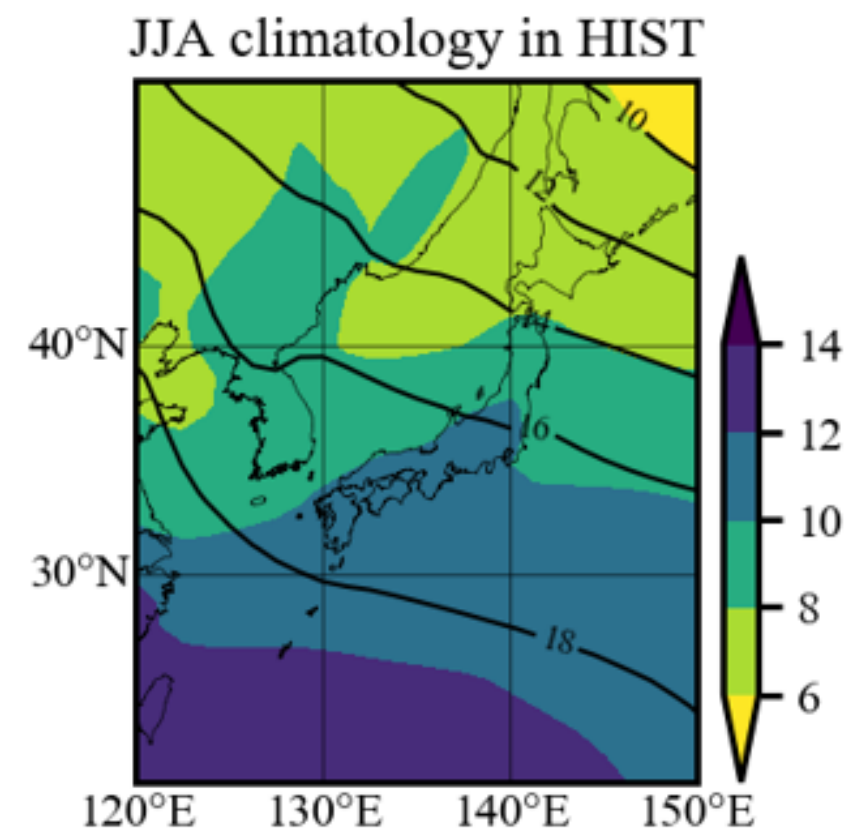

Figure 2

Ensemble-mean climatology at $850 \mathrm{hPa}$ in JJA for the HIST run. Contours show the temperature at 850 $\mathrm{hPa}$ with an interval of $2 \mathrm{~K}$ and the shading shows the specific humidity at $850 \mathrm{hPa}(\mathrm{g} \mathrm{kg}-1)$ as per the scale on the right. 
(a) Temperature

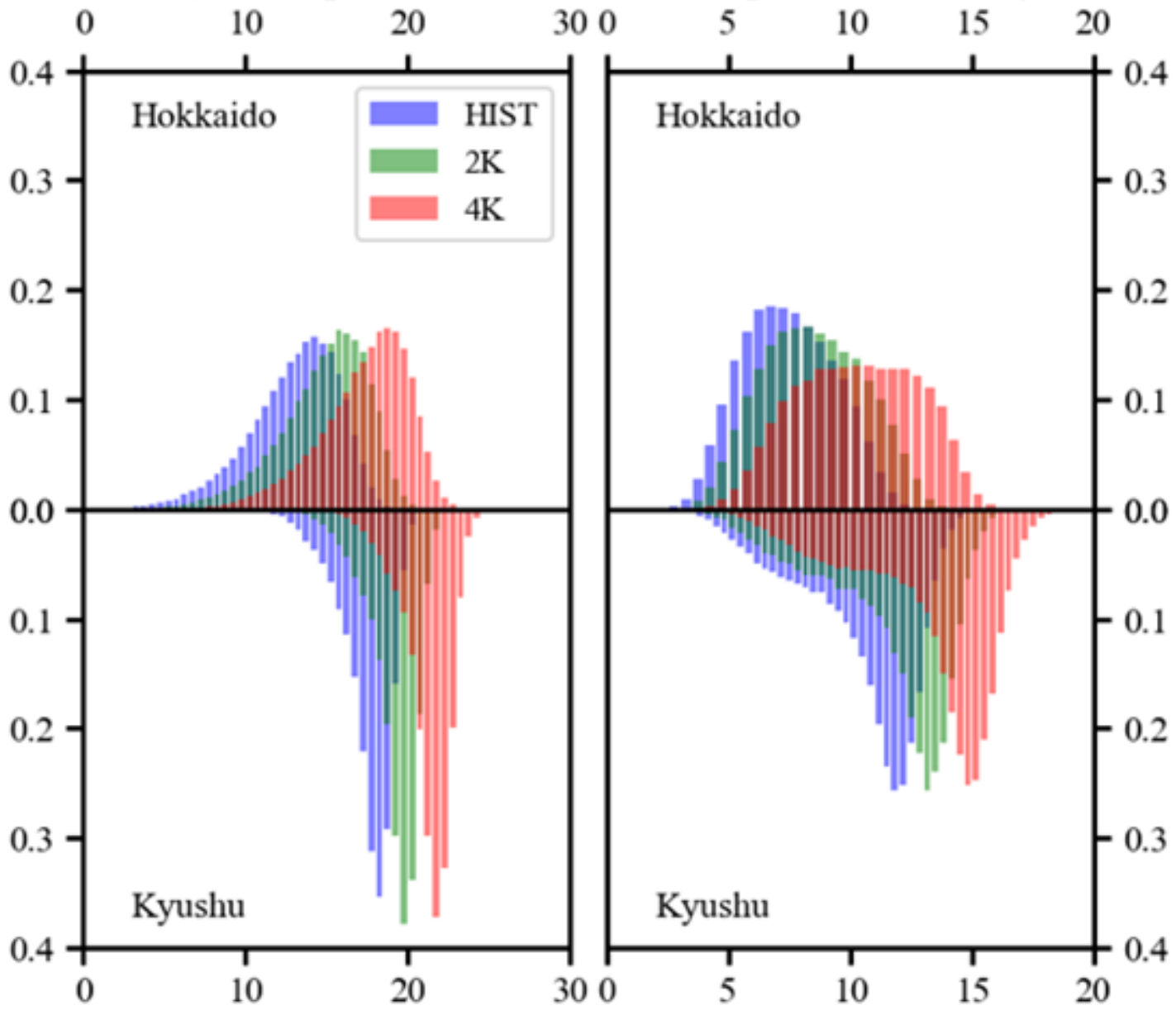

Figure 3

Frequency distribution of pentad mean (a) temperature and (b) specific humidity at $850 \mathrm{hPa}$ in JJA (upper half) in Hokkaido and (lower half) in Kyushu for the (blue) HIST, (green) 2K, and (red) 4K runs. 


\section{JJA climatology diff.}

(a) $2 \mathrm{~K}$ minus HIST

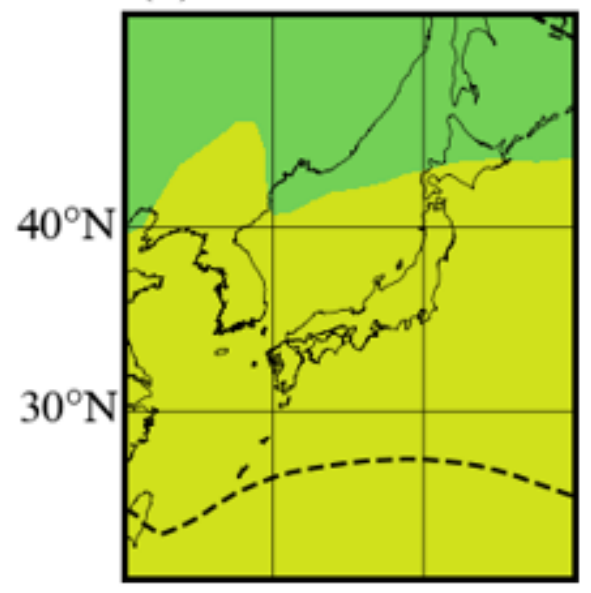

(b) 4K minus HIST

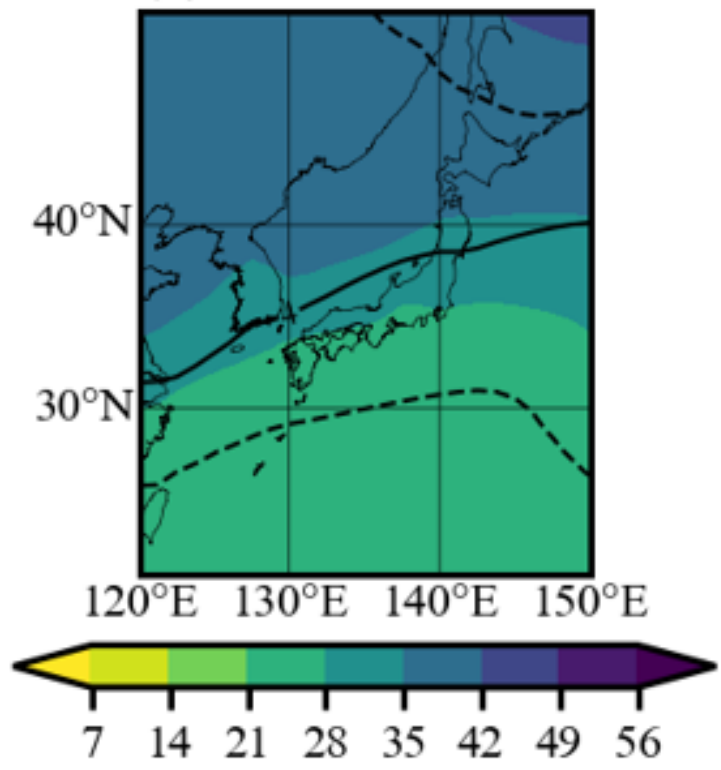

\section{Figure 4}

Difference of ensemble-mean climatology at $850 \mathrm{hPa}$ in JJA (a) between the $2 \mathrm{~K}$ and HIST runs and (b) between the $4 \mathrm{~K}$ and HIST runs. Contours show the temperature difference at $850 \mathrm{hPa}$ with an interval of $0.5 \mathrm{~K}$ and dashed for half integer values, and the shading shows the relative difference of specific humidity (\%) as per the scale at the bottom. 


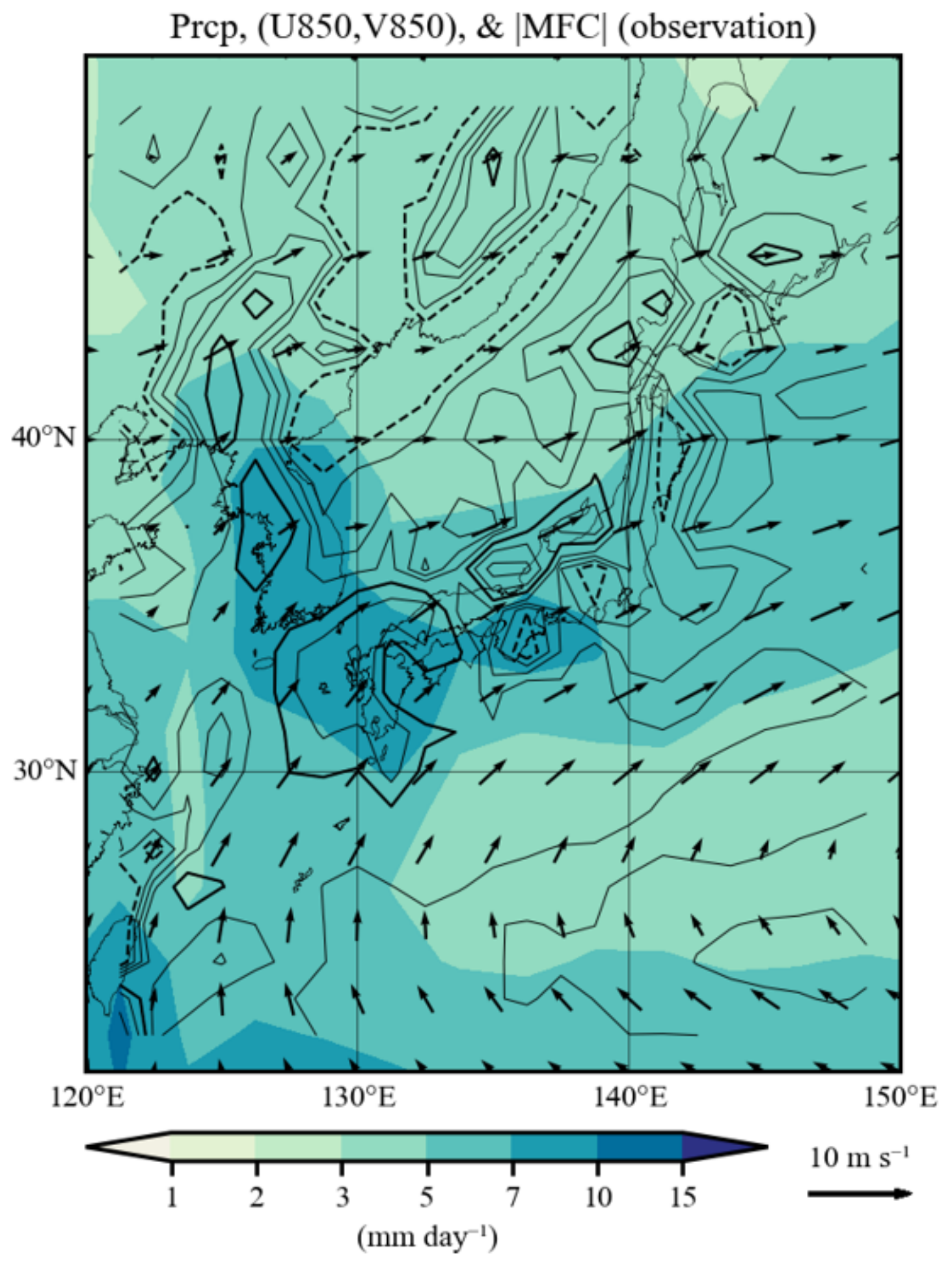

Figure 5

JJA-month climatology based on JRA-55 reanalysis data and GPCP precipitation data (Adler et al. 2003) from 1979 to 2020. The color shading shows the precipitation as per the scale at the bottom $(\mathrm{mm}$ day-1). The contour shows the vertically integrated MFC with contour lines at 1, 2, 3, 5, 7, 10, and $15 \mathrm{~mm}$ day -1 . The contours for 0 and $5 \mathrm{~mm}$ day- 1 are dashed and thickened, respectively. The vector shows the horizontal wind at $850 \mathrm{hPa}$ as the reference vector for $10 \mathrm{~m} \mathrm{~s}-1$ in the bottom right. 


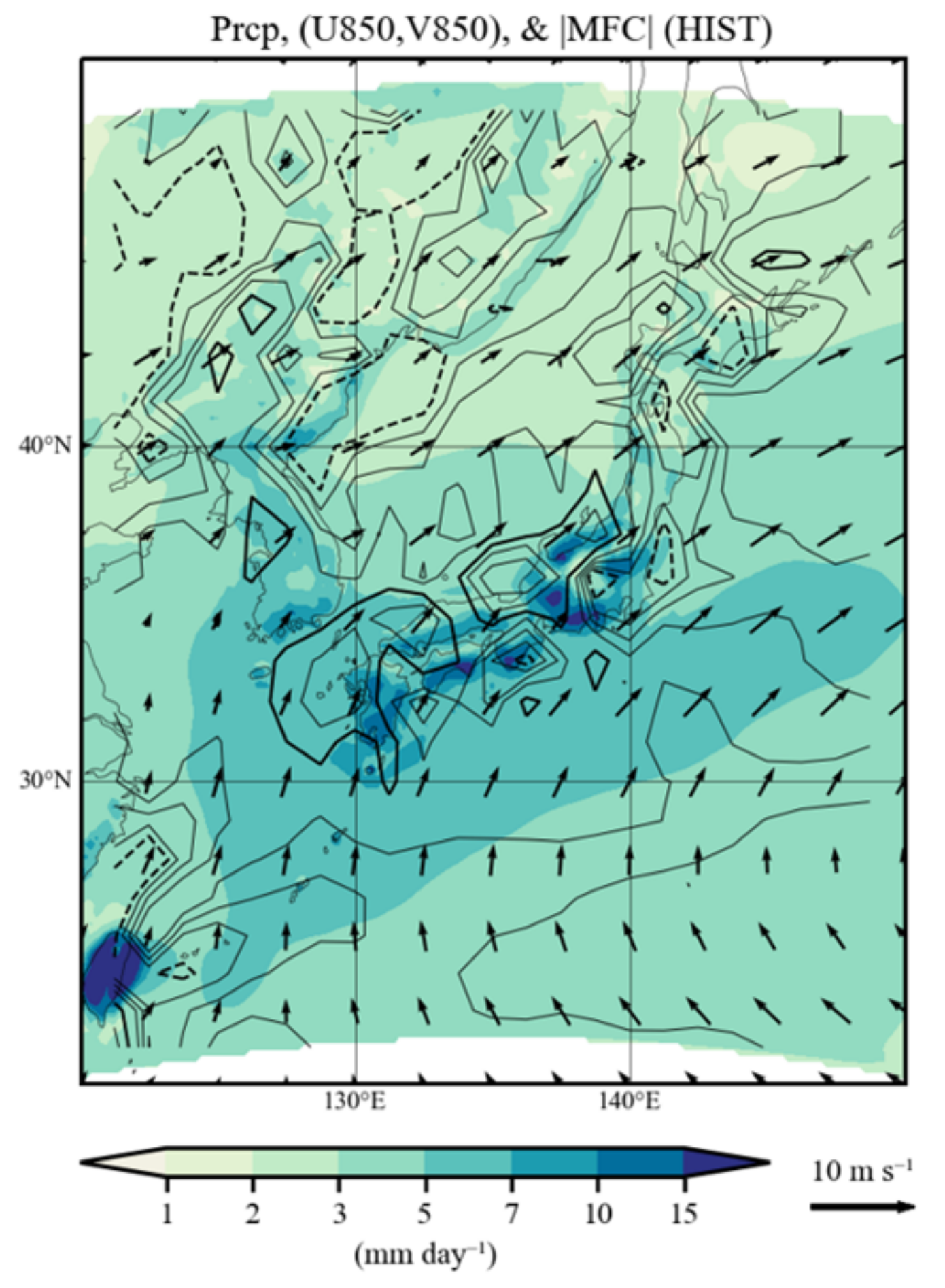

Figure 6

Ensemble-mean values averaged over JJA in the HIST run. The color shading shows the precipitation as per the scale at the bottom ( $\mathrm{mm}$ day-1). The contour shows the vertically integrated MFC with the contour lines at $1,2,3,5,7,10$, and $15 \mathrm{~mm}$ day-1. The contours for 0 and $5 \mathrm{~mm}$ day-1 are dashed and thickened, respectively. The vector shows the horizontal wind at $850 \mathrm{hPa}$ as the reference vector of $10 \mathrm{~m}$ s-1 in the bottom right. 


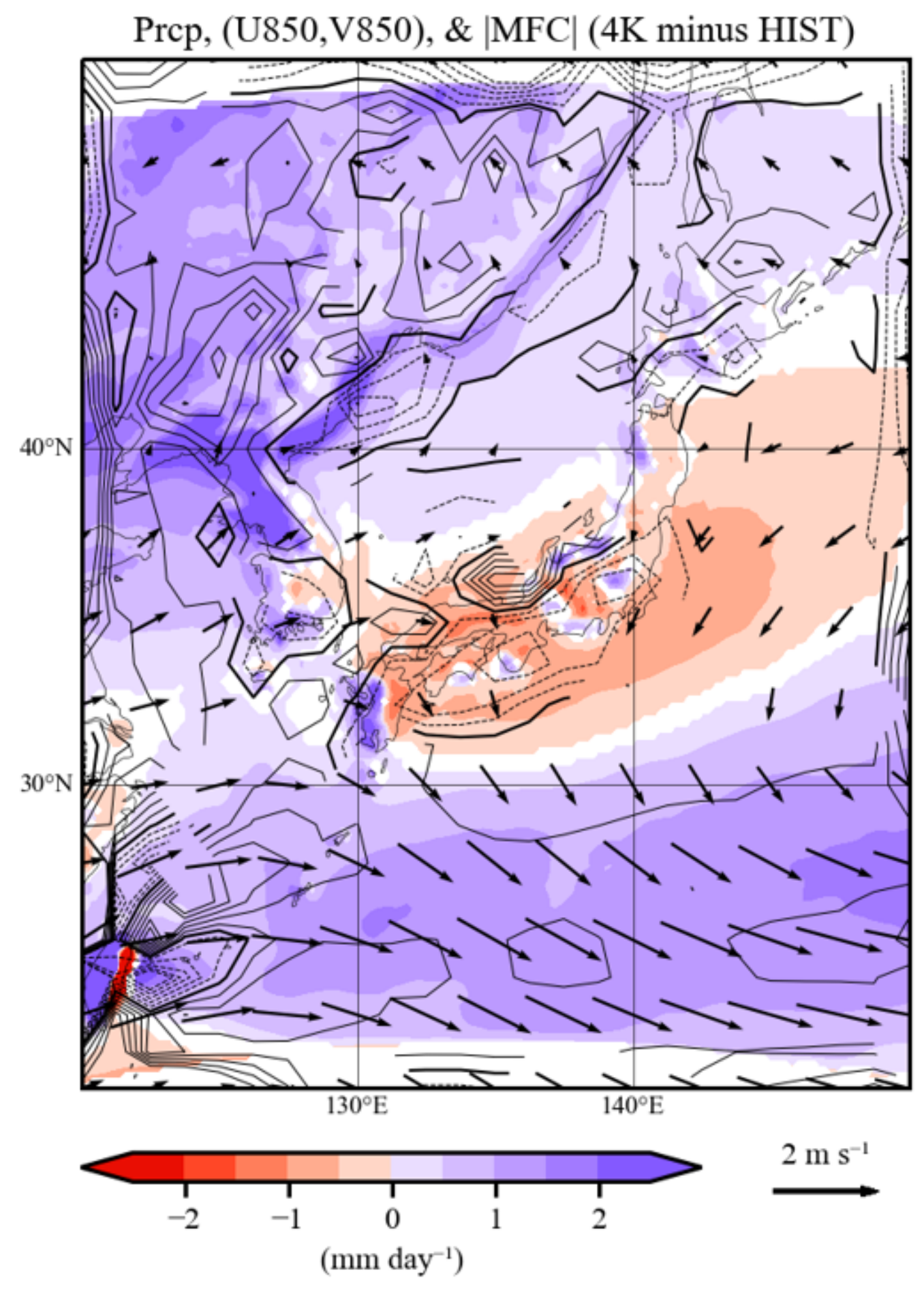

Figure 7

Precipitation difference of the ensemble mean values averaged over JJA between the 4K and HIST runs as per the color scale at the bottom ( $\mathrm{mm}$ day-1). The contours show the difference of vertically integrated MFC with an interval of $0.5 \mathrm{~mm}$ day-1. Negative contours are dashed and the zero contour is thickened. The vector shows the difference of horizontal wind at $850 \mathrm{hPa}$ as the reference vector of $2 \mathrm{~m}$ $s^{-1}$ in the bottom right. Signals below the statistical significance level of $5 \%$ were masked out. 

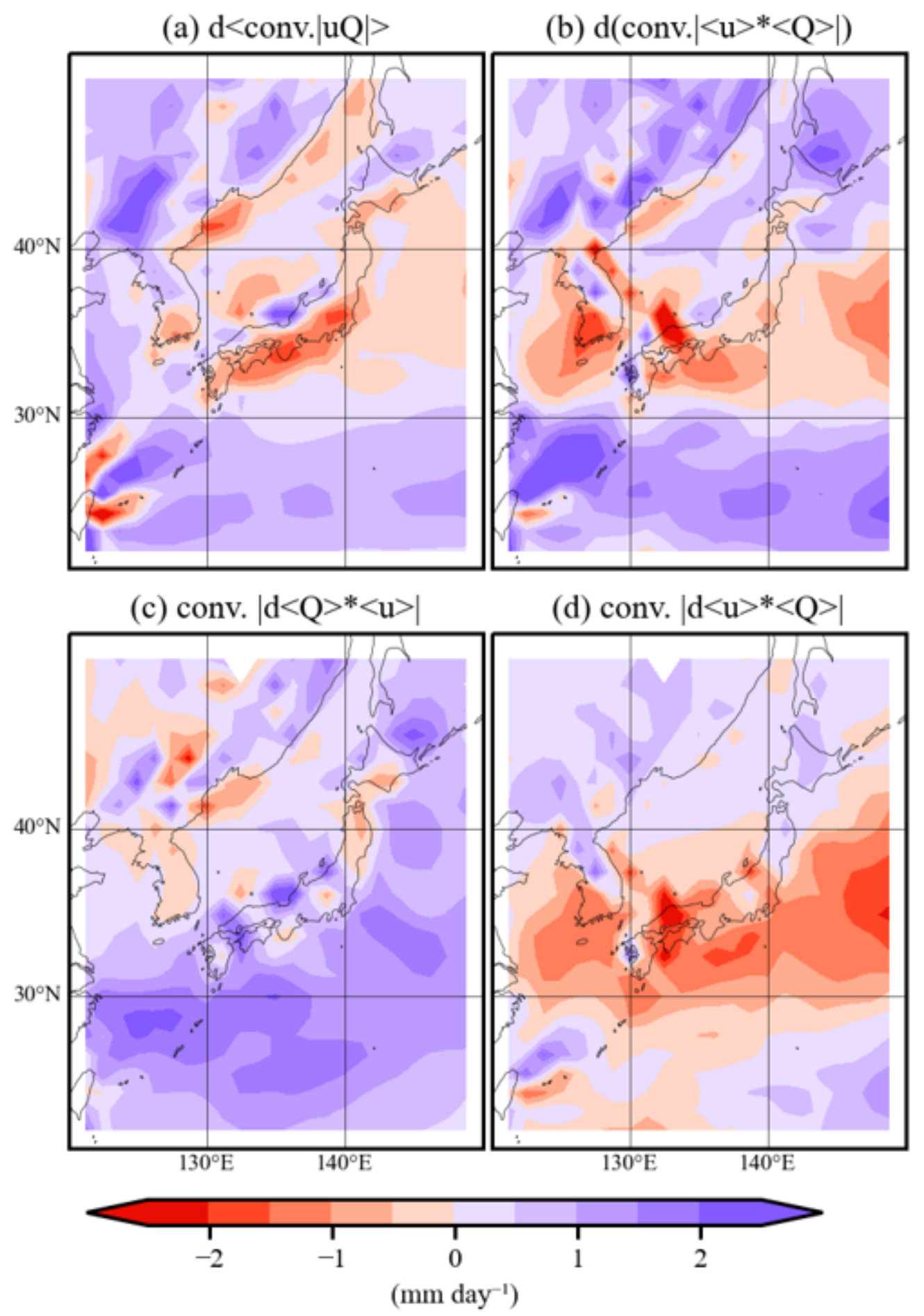

\section{Figure 8}

(a) Climatological difference of vertically integrated MFC between the 4K and HIST runs ( $\mathrm{mm}$ day-1; as per the color scale in the bottom). (b) Difference in vertically integrated MFC based on climatological wind and humidity between the runs. (c,d) Contribution of climatological (c) humidity and (d) wind difference to (b). 
(a) U500(HIST)

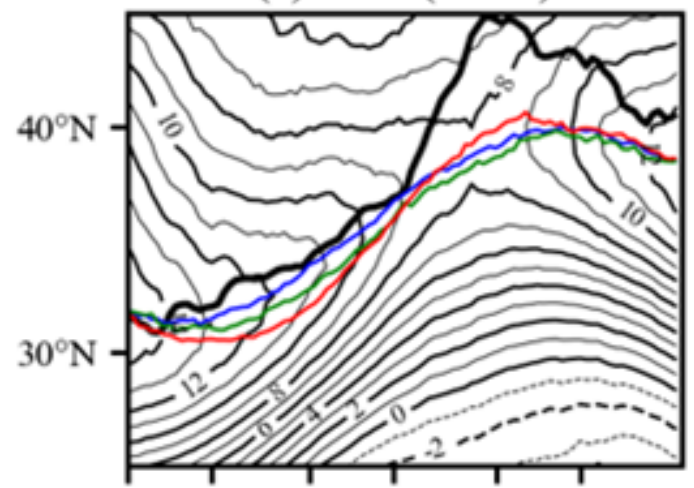

(c) $\mathrm{U} 500(4 \mathrm{~K})$

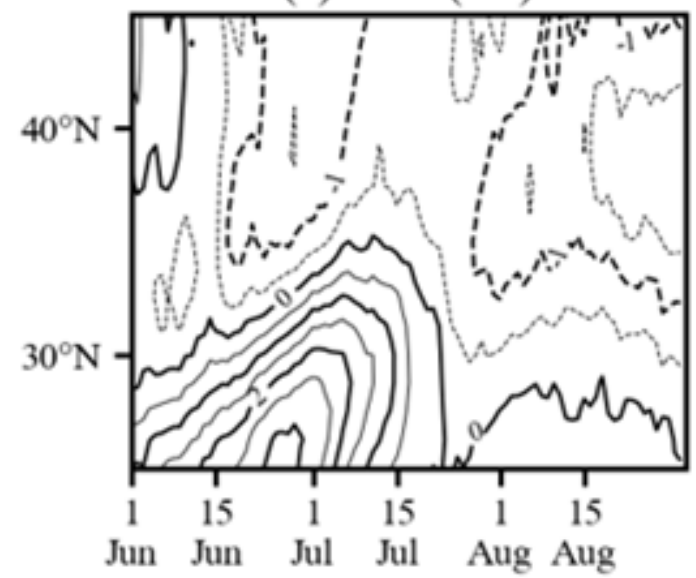

(b) SLP(HIST)

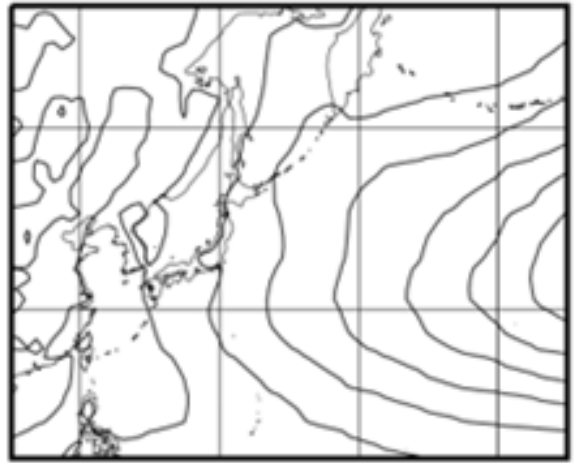

(d) SLP(4K)

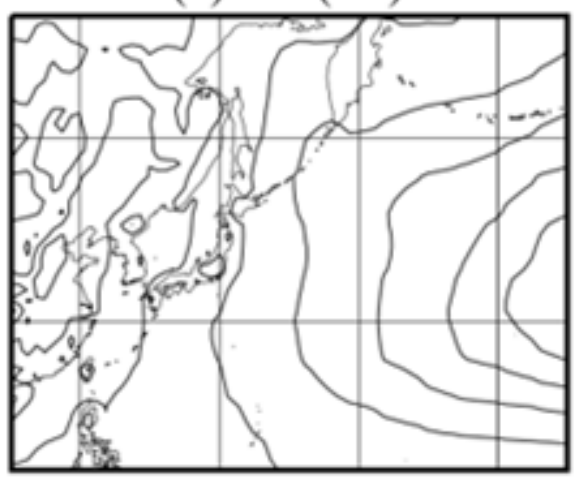

\section{Figure 9}

(a) Climatological zonal wind at $500 \mathrm{hPa}(\mathrm{m} \mathrm{s}-1)$ averaged between $130^{\circ} \mathrm{E}$ and $140^{\circ} \mathrm{E}$ for the HIST run. The contour interval is $1 \mathrm{~m} \mathrm{~s}^{-1}$ and negative contours are dashed. Blue, green, and red lines in (a) indicate the local maximum of zonal wind for the HIST, $2 \mathrm{~K}$, and $4 \mathrm{~K}$ runs, respectively, and the black line in (a) indicates that for the observed climatology. (b) Climatological sea level pressure (SLP) in JJA for the HIST runs, with a contour interval of $2 \mathrm{hPa}$. (c) Difference between the 4K and HIST runs with a contour interval of $1 \mathrm{~m} \mathrm{~s}^{-1}$. (d) Climatological SLP in JJA for the 4K run. 
(a) U500

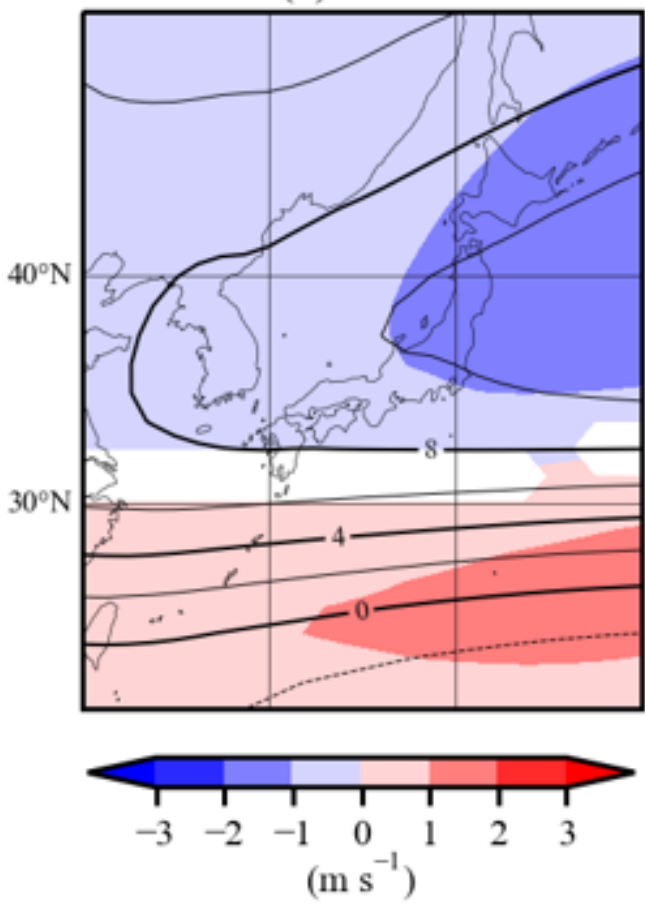

(c) $\mathrm{V}_{\mathrm{H}} \mathrm{Q}_{\mathrm{H}} 850$

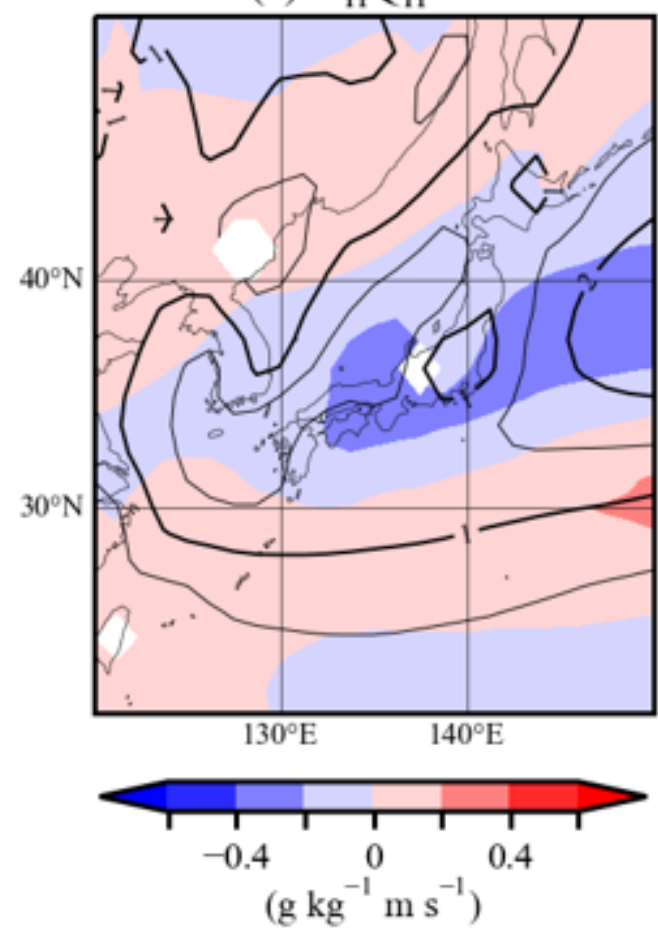

(b) $\mathrm{V}_{\mathrm{H}} \mathrm{V}_{\mathrm{H}} 500$

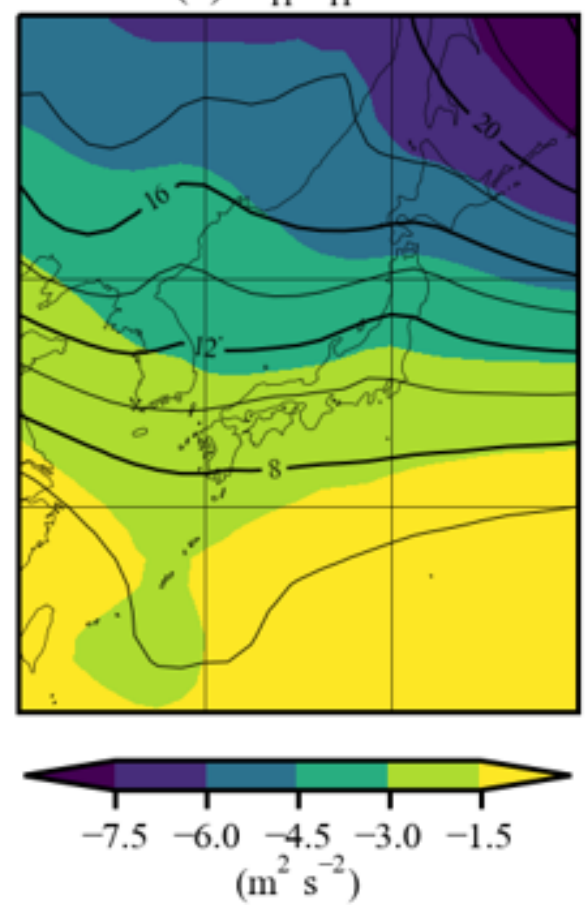

(d) MFC by transient eddies

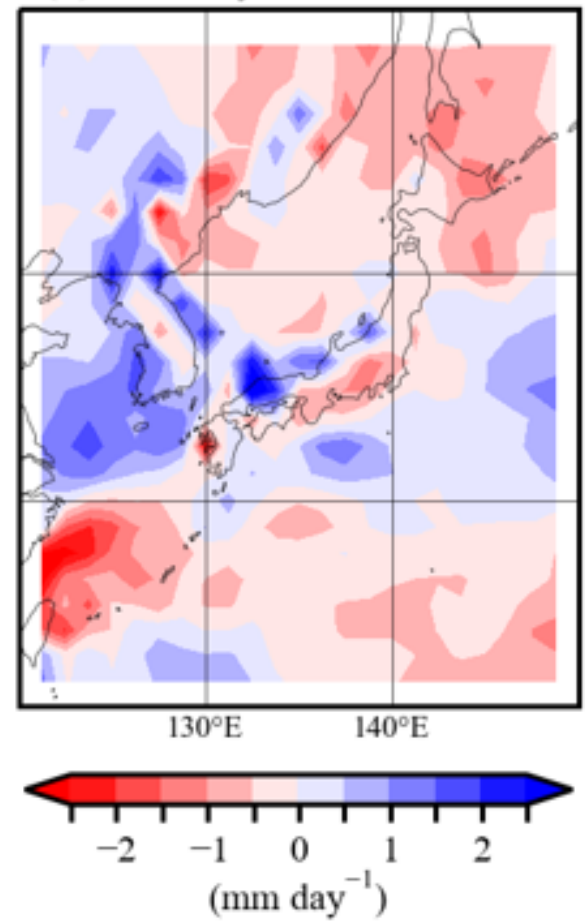

Figure 10

(Contours) HIST's climatology and (color shading) the difference between the $4 \mathrm{~K}$ and HIST runs as per the scale at the bottom of each panel. Nonsignificant signals are masked out in panels (a)-(c). (a) Zonal wind at $500 \mathrm{hPa}$ with a contour interval of $2 \mathrm{~m} \mathrm{~s}-1$. (b) Storm activity estimated with the variance of band-pass-filtered meridional wind at $500 \mathrm{hPa}$. The filter passes signals that have a period of 2-8 days. The contour interval is $2 \mathrm{~m} 2 \mathrm{~s}-2$. (c) Meridional moisture flux caused by band-pass-filtered fluctuations 
at $850 \mathrm{hPa}$, with a contour interval of $0.5 \mathrm{~g} \mathrm{~kg}-1 \mathrm{~m} \mathrm{~s}-1$. (d) Difference in vertically integrated MFC caused by transient eddies between $4 \mathrm{~K}$ and HIST runs ( $\mathrm{mm}$ day -1 ).

\section{TC contribution rate (HIST)}

(a) Hokkaido

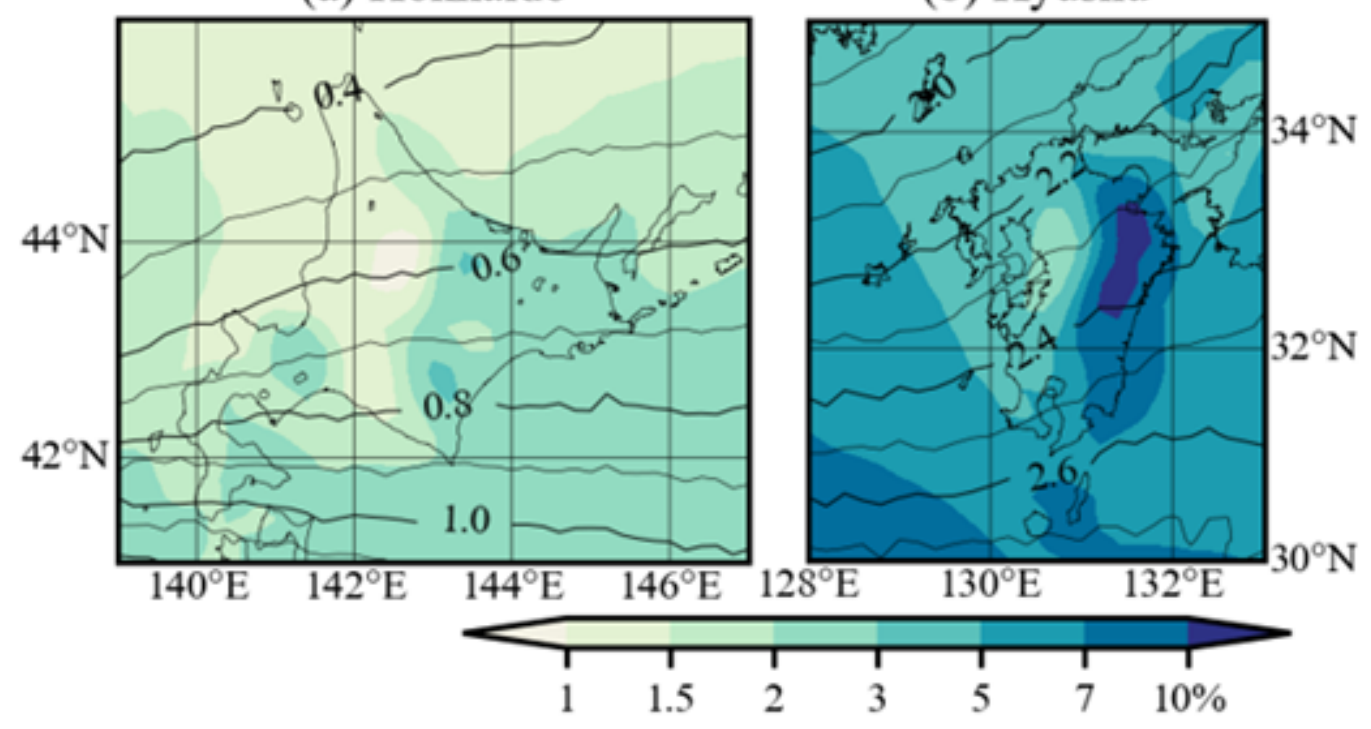

Figure 11

Contribution of tropical cyclones to total JJA precipitation (a) in Hokkaido and (b) in Kyushu, with the color shading as per the scale at the bottom right (\%). Contours show the average number of tropical cyclones passing over the grid per year. 
(a) Hokkaido (2K/HIST)

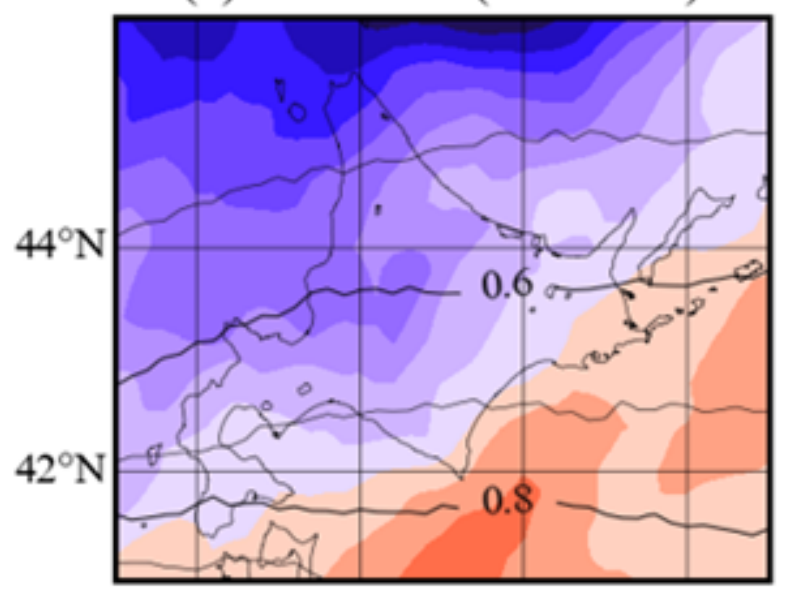

(c) Hokkaido (4K/HIST)

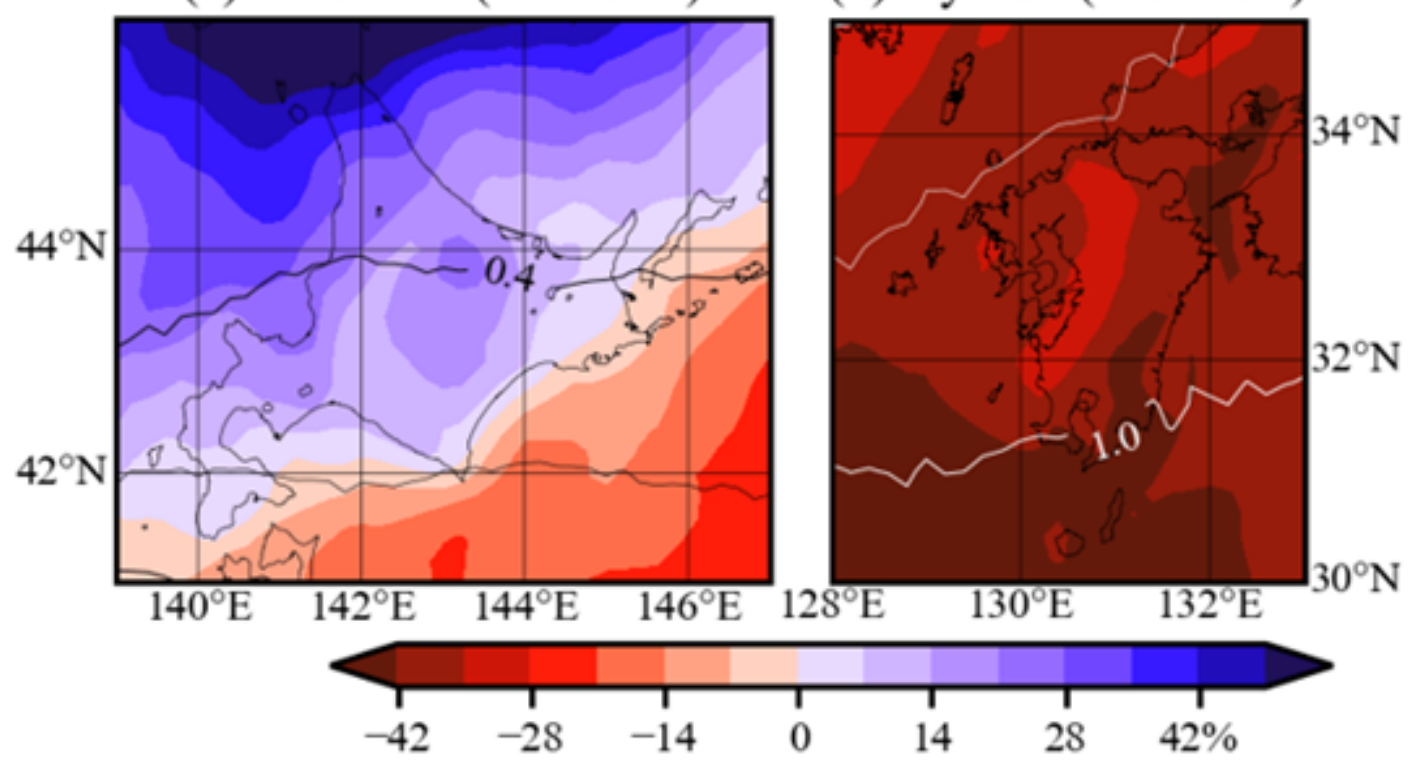

(b) Kyushu (2K/HIST)

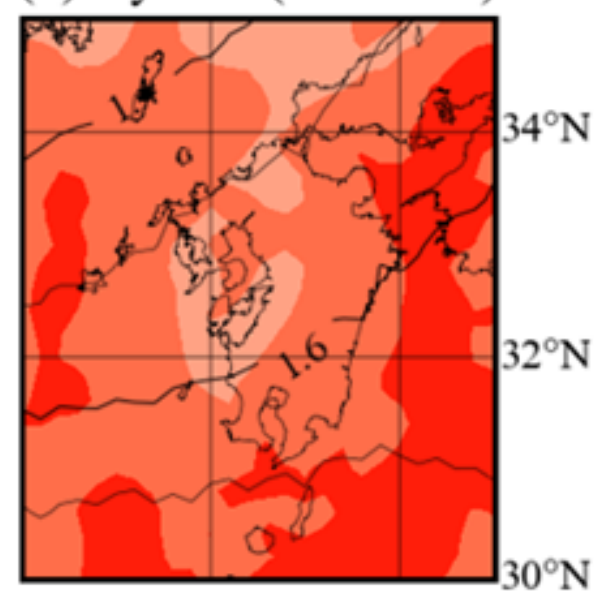

(d) Kyushu (4K/HIST)

.




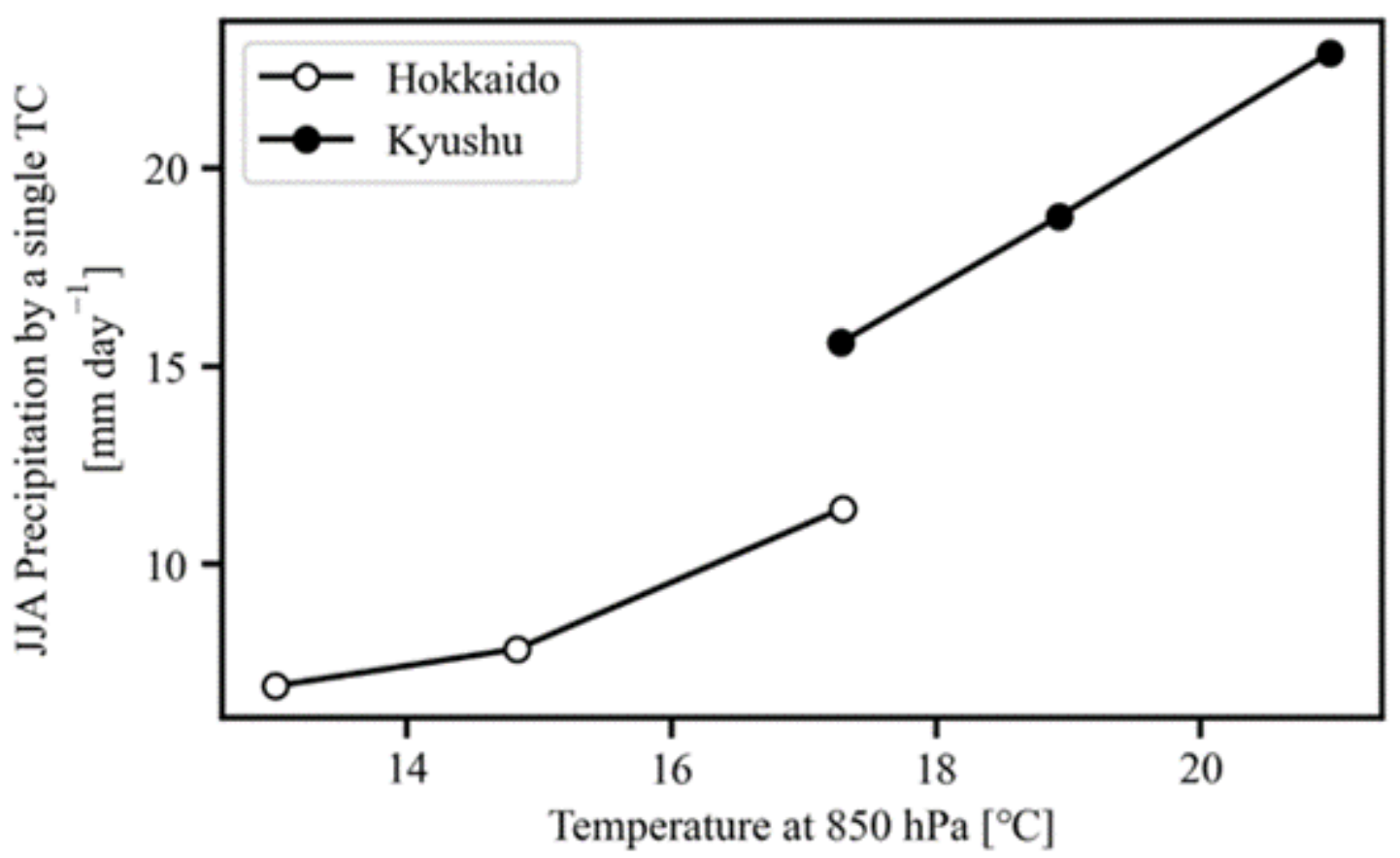

Figure 13

JJA precipitation ( $\mathrm{mm}$ day -1 ) by a single TC (line with open circles) averaged over Hokkaido and (line with closed circles) averaged over Kyushu, as a function of area-averaged air temperature at $850 \mathrm{hPa}$. The results of the HIST, $2 \mathrm{~K}$, and $4 \mathrm{~K}$ runs are aligned from left to right. 